\title{
Keefektifan Model Think Talk Write Berbantu Media Gambar Seri terhadap Keterampilan Menulis
}

\author{
Afif Zaenal Arifin ${ }^{1 *}$, Choirul Huda ${ }^{2}$, Ikha Listyarini ${ }^{3}$
}

${ }^{123}$ PGSD FIP Universitas PGRI Semarang

\section{A R T I C LEINFO}

\section{Article history:}

Received 18 May 2019

Received in revised form 30 June 2019

Accepted 15 July 2019

Available online 25 August 2019

\section{Kata Kunci:}

Think Talk Write, gambar

seri, keterampilan menulis.

\section{Keywords:}

Think Talk Write, series drawings, writing skills

\begin{abstract}
A B S T R A K
Tujuan dalam penelitian ini adalah untuk mengetahui keefektifan model Think Talk Write berbantu media gambar seri dalam pembelajaran Bahasa Indonesia materi menulis karangan narasi pada siswa kelas V SD Negeri Bugangan 02 Semarang. Jenis penelitian ini adalah eksperimen menggunakan Pre Experimental Design yang digunakan adalah One Group Pretest-Posttest Design. Populasi penelitian adalah seluruh siswa SD N Bugangan 02 Semarang tahun pelajaran 2018/2019. Sampel yang diambil adalah 29 siswa kelas V. Data dalam penelitian ini diperoleh melalui observasi, tes, dan dokumentasi. Berdasarkan analisis akhir yang telah dilakukan terlihat dari nilai posttest yang menunjukan pembelajaran dengan model Think Talk Write berbantu media gambar seri lebih baik daripada menggunakan pembelajaran konvensional. Hal tersebut diperkuat dengan hasil analisis akhir yang telah dilakukan dengan menggunakan uji t menunjukan bahwa thitung $>$ ttabel yaitu 10,239 $>2,370$ dengan $\mathrm{db}$ $\mathrm{N}-1=29-\quad 1=28$, dan taraf signifikan $5 \%$ diperoleh ttabel=2,370 karena thitung >ttabel maka $\mathrm{HO}$ ditolak dan $\mathrm{Ha}$ diterima sehingga dapat disimpulkan bahwa efektif penerapan model pembelajaran Think Talk Write berbantu media gambar seri dalam pembelajaran bahasa Indonesia materi menulis karangan narasi pada siswa kelas $\mathrm{V}$ SD Negeri Bugangan 02 Semarang.
\end{abstract}

\section{A B S T R A C T}

The problem in this research was to find out the effectiveness of the Think Talk Write model with picture series media in Indonesian language learning material in writing narrative essays in fifth grade students of SD Negeri Bugangan 02 Semarang. This type of research was an experiment using Pre Experimental Design which One Group Pretest-Posttest Design. The study population was all students of SD N Bugangan 02 Semarang 2018/2019 academic year. Samples taken were 29 fifth grade students. The data in this study were obtained through observation, tests, and documentation. Based on the final analysis that has been done, it can be seen from the posttest value that shows that learning with the Think Talk Write model with the help of serial image media is better than using conventional learning. The results of the final analysis that has been done by using the t test showed that tcount $>$ ttable is $10.239>2.370$ with $\mathrm{db} \mathrm{N}-1=29-1=28$, and a significant level was $5 \%$ obtained ttable $=2.370$. tcount $>$ ttable then $\mathrm{HO}$ was rejected and $\mathrm{Ha}$ was accepted so that it could be concluded that Think Talk Write learning model by serial picture media in Indonesian language learning material is effective in writing narrative essays at fifth grade students of SD Negeri Bugangan 02 Semarang.

\footnotetext{
${ }^{1}$ Corresponding author.

E-mail addresses: afifzaenal0@gmail.com (Afif Zaenal Arifin)
} 


\section{Pendahuluan}

Menulis merupakan kegiatan yang sering dilakukan oleh setiap orang. Menulis juga suatu proses penyampaian gagasan, sikap, dan pendapat. Menulis memerlukan keterampilan tambahan bahkan motivasi tambahan pula, hal ini dikarenakan menulis bukan bakat karena tidak semua orang mampu untuk menulis. Selain itu, menulis merupakan aktivitas komunikasi yang menggunakan bahasa sebagai medianya. Dengan demikian, seseorang yang sedang menulis dapat mengungkapkan hasil pikiran dan gagasan untuk mencapai tujuannya.

Menurut Susanto (2015:246) menyatakan bahwa, menulis merupakan kegiatan yang paling sering dilakukan oleh setiap orang. Menulis membutuhkan keterampilan khusus yang harus dipelajari dan senantiasa dilatih. Menulis memerlukan keterampilan tambahan bahkan motivasi tambahan pula, hal ini dikarenakan menulis bukan bakat karena tidak semua orang mampu untuk menulis.

Berdasarkan hasil observasi dengan melakukan tanya jawab dengan guru kelas V SDN Bugangan 02 Semarang, diperoleh informasi bahwa siswa di Sekolah Dasar masih mengalami kesulitan dalam pelajaran khususnya pelajaran bahasa Indonesia yang mendapat rata-rata nilai 54,33 yang secara klasikal belum mencapai Kriteria Kentuntasan Minimal (KKM) yaitu 70.

Bersumber diskusi dengan guru kelas $\mathrm{V}$ dan mempertimbangkan kemungkinan pembelajaran yang cocok diterapkan dikelas, serta guru belum pernah menerapkan media maupun model yang diajarkan pada murid. Maka peneliti menetapkan pemecahan masalah berupa keefektifan model Think Talk Write (TTW) untuk meningkatkan keterampilan menulis narasi berbantu media gambar seri. Pemilihan model Think Talk Write (TTW) model pembelelajaran di karenakan model TTW memungkinkan siswa untuk berpartisipasi secara aktif dalam pembelajaran guna meningkatkan penguasaan keterampilan menulis siswa. Shoimin (2014:212) mengatakan Think Talk Write merupakan suatu model pembelajaran untuk melatih keterampilan peserta didik dalam menulis. Think Talk Write menekankan perlunya peserta didik mengomunikasikan hasil pemikirannya".

Salah satu model pembelajaran yang dapat membuat siswa terlihat aktif dan mendukung siswa dalam mengembangkan keterampilan berargumentasi baik secara lisan maupun tulisan adalah model kooperatif tipe Think-Talk-Write (TTW). Menurut Dewayani (2019) Pembelajaran merupakan suatu aktivitas yang mengakibatkan terjadinya suatu interaksi antara guru dengan siswa. Pembelajaran melahirkan suatu pengalaman baru bagi guru dan siswa, sebuah pembelajaran dikatakan berhasil apabila tujuan adanya pembelajaran itu sendiri telah tersampaikan oleh karena itu guru harus merancang berbagai model, strategi dan model pembelajaran yang menarik, terutama bila diterapkan bagi anak berkebutuhan khusus. Salah satu contohnya dalam kegiatan pembelajaran anak tunarungu. TTW adalah model pembelajaran yang dimulai dari aktivitas berpikir (Think) melalui bahan bacaan, setelah tahap think dilanjutkan dengan tahap talk yaitu dengan diskusi, siswa melakukan komunikasi dengan menggunakan kata -kata dan bahasa yang mereka pahami. Pada tahap ini diharapkan siswa mampu berinteraksi dengan teman - temannya sendiri. Tahap terakhir adalah write yaitu menulis hasil dikusi pada lembar kerja yang telah disediakan.

Menurut Huinker dan Laughlin (dalam Handayana 2014:217) model pembelajaran think talk write dibangun melalui berpikir, berbicara, dan menulis. Alur kemajuan strategi TTW dimulai dari keterlibatan siswa dalam berpikir atau berdialog dengan dirinya sendiri setelah proses membaca. Selanjutnya, berbicara dan membagi ide (sharring) dengan temannya sebelum menulis. Suasana seperti ini lebih efektif jika dilakukan dalam kelompok heterogen dengan 3-5 siswa. Dalam kelompok ini, siswa diminta membaca, membuat catatan kecil, menjelaskan, menyimak dan membagi ide bersama teman kemudian megungkapkannya melalui tulisan. Menurut Sugandi (2011:52) Think-Talk-Write (TTW) adalah model pembelajaran yang berusaha membangun pemikiran merefleksi, dan mengorganisasi ide, kemudian menguji ide tersebut sebelum siswa diharapkan untuk menuliskan ide-ide tersebut. Model pembelajaran Think Talk Write (TTW) adalah sebuah pembelajaran yang dimulai dengan berpikir melalui bahan bacaan (menyimak, mengritisi, dan alternatif solusi), hasil bacaannya dikomunikasikan dengan presentasi, diskusi, dan kemudian membuat laporan hasil presentasi (Siswanto dan Ariani, 2016: 107). Model pembelajaran Think Talk Write (TTW) membangun pemikiran, merefleksi, dan mengorganisasi ide, kemudian menguji ide tersebut sebelum peserta didik diharapkan untuk menulis (Siswanto dan Ariani, 2016: 107). Langkah-langkah model Think Talk Write (TTW) (Shoimin, 2014: 212-214) adalah sebagai berikut: (1) guru membagikan LKS, (2) peserta didik membaca masalah dan membuat catatan kecil, (3) membagi siswa dalam kelompok kecil (3-5 siswa), (4) siswa berdiskusi (5) peserta didik secara individu merumuskan jawaban tertulis dengan bahasa sendiri, (6) presentasi kelompok, (7) refleksi (Ratna ,2017). Menurut Hamdayama (2014:217) Think Talk Write adalah sebuah pembelajaran yang dimulai dengan berpikir melalui bahan bacaan (menyimak, mengkritisi, dan alternatif solusi), hasil bacaannya dikomunikasikan dengan presentasi, diskusi, dan kemudian membuat laporan hasil presentasi. Dalam 
proses pembelajaran siswa membaca suatu bacaan lalu berpikir dan membuat catatan kecil, dan kemudian menjelaskan kepada kelompoknya, sehingga setiap anggota kelompok saling menuangkan ide masing-masing, dan kemudian menuangkan hasil diskusi melalui tulisan. Sedangkan menurut Iru dan Arihi (2012:68) model pembelajaran Think Talk Write merupakan model pembelajaran dimana perencanaan dari tindakan yang cermat mengenai kegiatan pembelajaran yaitu melalui berpikir, bertukar pendapat, dan menuliskan hasil diskusi agar tujuan pembelajaran dapat tercapai. Menurut Hartanto (2017) model pembelajaran Think Talk Write menggunakan kelompokkelompok kecil dan menuntut siswa untuk bekerjasama, berdiskusi, berbagi ilmu pengetahuan, saling berkomunikasi, dan saling membantu untuk memahami materi pelajaran.

Dalam model ini, siswa dituntut untuk melakukan tiga aktifitas, yaitu berpikir (think), berbicara (talk), dan menulis (write). Menurut Setiyaningrum (2015) Model pembelajaran kooperatif tipe ThinkTalk-Write (TTW) merupakan suatu model pembelajaran yang dibangun melalui tiga hal yaitu berpikir, berbicara, dan menulis. Alur pembelajaran model Think-Talk-Write (TTW) dimulai dari keterlibatan siswa dalam berpikir dan berdialog dengan dirinya sendiri setelah proses membaca, selanjutnya berbicara dan membagi ide (sharing) dengan temannya sebelum menulis. Menurut Riski (2017) Model pembelajaran ini membuat siswa lebih berperan aktif dan berperan lebih dominan dibanding guru. Tugas guru dalam model pembelajaran TTW hanya sebagai fasilitator dan motivator dalam pembelajaran. Namun, guru sebagai fasilitator harus selalu memantau perkembangan aktivitas siswa dan mendorong siswa agar mencapai tujuan yang hendak dicapai. Menurut Irmayati (2015) Model pembelajaran berbasis komunikasi dengan strategi Think Talk Write (TTW) dapat membantu siswa dalam mengkonstruksi pengetahuannya sendiri sehingga pemahaman konsep siswa menjadi lebih baik, siswa dapat mengkomunikasikan atau mendiskusikan pemikirannya dengan temannya sehingga siswa saling membantu dan saling bertukar pikiran. Hal ini dapat membantu siswa dalam memahami materi yang diajarkan. Model pembelajaran berbasis komunikasi dengan strategi Think Talk Write (TTW) dapat melatih siswa untuk menuliskan hasil diskusinya ke bentuk tulisan secara sistematis sehingga siswa akan lebih memahami materi dan membantu siswa untuk mengkomunikasikannya. Menurut Riansyah (2018) Model TTW mendorong siswa untuk berfikir, berbicara dan kemudian menuliskan suatu topik tertentu. Model ini membantu siswa dalam mengumpulkan dan mengembangkan ide-ide melalui percakapan yang terstruktur.

Salah satu kelebihan model TTW adalah dengan berinteraksi dan berdiskusi dengan kelompok akan melibatkan siswa secara aktif dalam belajar. Maka model TTW memang sangat efektif untuk mengoptimalkan proses pembelajaran guna meningkatkan keterampilan menulis bahasa Indonesia Terhadap Keterampilan Menulis Siswa.

Oleh karena itu, guru harus memilih strategi dan model pembelajaran yang tepat. Penggunaan model pembelajaran yang tepat dapat menumbuhkan rasa senang siswa terhadap pembelajaran. Siswa akan termotivasi untuk aktif mengerjakan tugas dan memahami materi sehingga tujuan pembelajaran tercapai. Model pembelajaran ini mendorong siswa untuk berpikir, berbicara dan kemudian menuliskannya. Model Think Talk Write (TTW) memberikan kesempatan kepada siswa untuk bekerja sama dalam menyelesaikan masalah. Dan tak lupu juga dengan menggunakan media berupa gambar seri memungkinkan anak dapat menyusun kata demi kata dengan lebih baik, sehingga pembelajaran keterampilan menulis dapat diserap anak secara real dan anak juga tidak lagi merasa kesulitan membuat sebuah paragraf.

\section{Metode}

Jenis penelitian ini adalah eksperimen menggunakan Pre Experimental Design yang digunakan adalah One Group Pretest-Posttest Design. Populasi penelitian adalah seluruh siswa SD N Bugangan 02 Semarang tahun pelajaran 2018/2019. Sampel yang diambil adalah 29 siswa kelas V. Data dalam penelitian ini diperoleh melalui observasi, tes, dan dokumentasi. Berdasarkan analisis akhir yang telah dilakukan terlihat dari nilai posttest yang menunjukan pembelajaran dengan model Think Talk Write berbantu media gambar seri lebih baik daripada menggunakan pembelajaran konvensional. Hal tersebut diperkuat dengan hasil analisis akhir yang telah dilakukan dengan menggunakan uji t menunjukan bahwa thitung > ttabel yaitu 10,239 > 2,370 dengan db N-1=29- 1=28, dan taraf signifikan 5\% diperoleh ttabel=2,370 karena thitung >ttabel maka H0 ditolak dan Ha diterima. 


\section{Hasil dan Pembahasan}

Sebelum uji analisis data terlebih dahulu dilakukan uji analisis data awal yaitu uji normalitas, sedangkan untuk uji analisis data akhir antara kelompok eksperimen dan kelompok kontrol menggunakan uji-t. Uji-t dilakukan untuk mengetahui perbedaan hasil belajar siswa pretest sebelum diberikan perlakuan dan hasil posttest setelah diberi perlakuan. Uji-t ini diambil dari hasil pretest.

Tabel 1 Daftar Uji Normalitas Nilai Pretest

\begin{tabular}{llll}
\hline Nilai & L0 & Ltabel & Keterangan \\
\hline Pretest & 0,126 & 0,165 & Berdistribusi normal \\
\hline
\end{tabular}

Berdasarkan Tabel 1 di atas, hasil perhitungan data dari nilai Pretest diperoleh $\mathrm{L}_{0}=0,126$ dengan $\mathrm{n}$ $=29$ dan taraf nyata $\alpha=0,05$, dari daftar nilai kritis $\mathrm{L}$ didapat $\mathrm{L}_{\text {tabel }}=0,165$. Karena $\mathrm{L}_{0}<\mathrm{L}_{\text {tabel }}$ yaitu $0,126<$ 0,165 , maka $\mathrm{H}_{0}$ diterima sehingga dapat disimpulkan sampel berasal dari populasi berdistribusi normal.

Tabel 2 Daftar Uji Normalitas Nilai Posttest

\begin{tabular}{llll}
\hline Nilai & L0 & Ltabel & Keterangan \\
\hline Posttest & 0,148 & 0,165 & Berdistribusi normal \\
\hline
\end{tabular}

Berdasarkan Tabel 2 di atas, hasil perhitungan data dari nilai Posttest diperoleh $\mathrm{L}_{0}=0,148$ dengan $\mathrm{n}=29$ dan taraf nyata $\alpha=0,05$, dari daftar nilai kritis $\mathrm{L}$ didapat $\mathrm{L}_{\text {tabel }}=0,165$. Karena $\mathrm{L}_{0}<\mathrm{L}_{\text {tabel }}$ yaitu $0,148<$ $0,0,165$, maka $\mathrm{H}_{0}$ diterima sehingga dapat disimpulkan bahwa sampel berasal dari populasi berdistribusi normal.

Berdasarkan data hasil pretest dan posttest siswa kelas V SD Negeri Bugagan 02 Semarang Tahun Pelajaran 2018/2019 sebagai subjek penelitian dilakukan uji hipotesis untuk membuktikan keefektifan penerapan model Think Talk Write berbantu media gambar seri terhadap keterampilan menulis karangan narasi. Pengujian hipotesis berdasarkan hasil pretest dan posttest sebagai berikut.

Ho : Tidak ada keefektifan penerapan model Pembelajaran think talk write berbantu media gambar seri terhadap menulis karangan narasi siswa kelas kelas V SD Negeri Bugangan 02 Semarang.

Ha : Ada keefektifan penerapan model Pembelajaran think talk write berbantu media gambar seri terhadap menulis karangan narasi siswa kelas kelas V SD Negeri Bugangan 02 Semarang.

Tabel 3 Daftar Uji t-test Pretest dan Postest

\begin{tabular}{lll}
\hline Keterangan & Pretest & Posttest \\
\hline Rata-rata & 67,966 & 82,069 \\
$\mathrm{~N}$ & 29 & \\
Md & 14,103 & \\
$\sum \mathrm{X}^{2} \mathrm{~d}$ & 1540,690 & \\
Thitung & 10,239 & \\
Ttabel & 2,048 & \\
\hline
\end{tabular}

Berdasarkan analisis data Tabel 3 nilai prettest dan posttest dengan uji $t$ - test diperoleh nilai ratarata pretest sebesar 67,966 dan nilai rata-rata postest sebesar 82,069 diperoleh thitung $=10,239$ dengan $\mathrm{db} \mathrm{N}-1=29-1=28$ dengan taraf signifikan 5\% sebesar 2,048 karena thitung > ttabel maka Ho ditolak dan Ha diterima.

Untuk mengetahui apakah nilai ketuntasan hasil belajar siswa dapat dicapai atau tidak setelah diterapkan pembelajaran menggunakan model Think Talk Write kata berbantu media gambar seri $\geq$ KKM 70, maka digunakan rumus berikut :

$$
\mathrm{KBI}=\frac{\text { Jumlah jawaban yang benar }}{\text { Jumlah soal seluruhnya }} \times 100
$$

Ketuntasan belajar secara individual dinyatakan sudah tercapai apabila siswa telah mendapatkan nilai sekurang-kurangnya 70 . 
Ketuntasan belajar klasikal diharapkan dapat mencapai 70\%. Dalam menghitung ketuntasan hasil belajar menggunakan hasil Pretest dan Posttest.

Pretest $=6 / 29 \times 100 \%$

$=20,689 \%$

Hasil dari ketuntasan belajar klasikal pada pretest terlihat jelas masih kurangnya nilai untuk mencapai nilai maksimum atau lebih dari 75\% sehingga peneliti perlu mengatasinya dengan menerapkan model Think Talk Write berbantu media gambar seri.

Posttest $=27 / 9 \times 100 \%$

$=93,103 \%$

Hasil dari ketuntasan belajar klasikal pada Posttest dapat diketahui dengan pasti peningkatannya. Hal ini dikarenakan sudah diterapkan pembelajaran menggunakan model Think Talk Write berbantu media gambar seri. Berdasarkan hasil di atas, dapat disimpulkan bahwa model Think Talk Write berbantu media gambar seri dapat meningkatkan keterampilan menulis karangan siswa kelas V SD Negeri Bugangan 02 Semarang.

Penelitian ini menggukanan desain penelitian Pre Experimental Desain dengan bentuk One Group Pretest-Posttest Design yang dilaksanakan di SD Negeri Bugangan 02 Semarang pada siswa kelas V dengan jumlah siswa 29 orang. Penelitian di awali dengan melakukan observasi terhadap proses pembelajaran di sekolah yang akan diteliti. Berdasakan hasil pengamatan yang dilakukan peneliti, peneliti menemukan permasalahan yang ada dalam proses pembelajaran yaitu masalah mengenai keterampilan menulis karangan pada mata pelajaran Bahasa Indonesia. Dalam proses pembelajaran banyak siswa yang masih grogi, malu-malu dan tidak percaya dalam menulis karangan narasi di depan kelas.

Permasalahan tersebut dikarenakan guru pada saat proses pembelajaran menggunakan model konvensional seperti ceramah serta tidak adanya media yang mendukung dalam proses pembelajaran yang sedang berlangsung, sehingga menyebabkan keterampilan menulis siswa menjadi rendah. Dengan hasil pengamatan tersebut maka peniliti perlu meneliti permasalahan yang dihadapi.

Langkah awal yang dilakukan peneliti dalam melakukan penelitian ialah membuat sebuah alat ukur atau instrumen yang mampu membantu peneliti untuk mengukur apa yang akan diukur dalam pelaksanaan penelitian. Instrumen yang digunakan penelitian berupa lembar penelitian keterampilan menulis karangan yang berisi beberapa aspek yang harus dipenuhi dalam mengukur keterampilan menulis karangan narasi. Selain instrumen penilaian keterampilan menulis karangan tersebut penelitian juga akan menilai aktivitas siswa dengan sebelas indikator saat proses pembelajaran sebelum dan sesudah penggunaan model Think Talk Write berbantu media gambar seri. Penelitian ini dilakukan sebanyak tiga kali pertemuan dengan menyiapakan rencana pelaksanaan pembelajaran yang diserahkan oleh guru kelas. Dalam proses pembelajaran hari pertama peneliti memberikan materi yang akan diajarkan kemudian penelitian melakukan pretest dengan menilai keterampilan menulis karangan menggunakan instrument penilaian keterampilan menulis karangan tanpa menggunakan model Think Talk Write berbantu media gambar seri.

Alasan peneliti memilih menggunakan model pembelajaran Think Talk Write (TTW) berbantu media gambar seri, karena model pembelajaran ini dapat meningkatkan keaktifan siswa dalam proses pembelajaran. Dengan menggunakan model pembelajaran ini siswa mampu berfikir (Think), berbicara (Talk), dan menulis (Write). Dalam model pembelajaran Think Talk Write (TTW) dimulai dari keterlibatan siswa dalam berpikir atau berdialog dengan dirinya sendiri setelah proses membaca, selanjutnya berbicara dan membagi ide dengan temannya sebelum menulis. Suasana ini lebih efektif jika dilakukan dalam kelompok heterogen dengan 3-6 siswa.

Pada saat pretest didapatkan nilai rata-rata sebesar 67,996 sedangkan setelah diberikan perlakuan dengan menggunakan model pembelajaran Think Talk Write berbantu media gambar seri didapatkan nilai rata-rata posttest sebesar 82,069. Dengan demikian terjadi peningkatan nilai dari sebelum dan setelah menggunakan model pembelajaran Think Talk Write berbantu media gambar seri. Selain mengalami peningkatan pada hasil belajar siswa yang berupa aspek kognitif, pembelajaran menggunakan model pembelajaran Think Talk Write berbantu media gambar seri juga dapat meningkatkan penilaian sikap siswa yang berupa aspek afektif.

Selanjutnya untuk menguji hipotesis terdapat keefektifan model pembelajaran Think Talk Write berbantu media gambar seri dalam pembelajaran bahasa Indonesia materi menulis karangan narasi pada siswa kelas V SD Negeri Bugangan 02 Tahun Ajaran 2018/2019 maka dilakukan uji t-test. Dengan menggunakan uji t-test didapatkan nilai $t$ sebesar 10,239 dengan ttabel $=2,048$. Karena thitung $>$ ttabel maka hipotesis dapat diterima atau menunjukkan bahwa terdapat keefektifan penerapan model 
pembelajaran Think Talk Write berbantu media gambar seri dalam pembelajaran bahasa Indonesia materi menulis karangan pada siswa kelas V SD Negeri Bugangan 02 Semarang.

Model pembelajaran Think Talk Write mendorong siswa untuk berpikir, berbicara, dan kemudian menuliskan suatu topik tertentu. Strategi Think Talk Write dimulai dari siswa diajak untuk berpikir (think) melalui lembar bacaan yang diberikan pada siswa.

Selanjutnya penggunaan gambar seri sebagai media komunikasi mempunyai kemampuan menyesuaikan diri yang luar biasa sehingga kadang digunakan untuk berbagai tujuan (Firdaus, 2010:70). Pemanfaatan gambar seri bisa disesuaikan dalam berbagai konteks tujuan, tidak terkecuali dalam dunia pendidikan sebagai media pembelajaran. Gambar seri dalam pembelajaran tentu harus dipilih yang mengandung unsur pendidikan. Sebagai media pembelajaran, gambar seri dapat memberikan hiburan kepada peserta didik sekaligus sebagai media belajar.

Berkaitan pemahaman dengan karakteristik peserta didik kelas $\mathrm{V}$, model Think Talk Write berbantu media gambar seri telah sesuai dengan teori belajar para ahli yang mendukung penelitian ini, diantaranya teori belajar Piaget dan teori konstruktivisme. Berdasarkan teori belajar Piaget, peserta didik kelas V Sekolah Dasar termasuk berada pada tahap operasional konkret dalam berpikir. Pada tahap operasional konkret, hendaknya dalam memberikan materi pelajaran, guru diharapkan lebih menitikberatkan model dan media yang lebih bersifat konkret dan logis. Sedangkan berdasarkan teori konstruktivisme yaitu guru tidak sekedar memberikan pengetahuan kepada siswa, namun siswa harus membangun sendiri pengetahuan yang ada dibenaknya. Dengan menggunakan model Think Talk Write berabantu media gambar seri ini siswa menjadi lebih berani dan percaya diri mereka memerankan sebuah peran secara langsung dengan pengetahuan yang mereka miliki sebelumnya sehingga terlihat lebih konkrit dan lebih jelas dalam memahami cerita yang mereka peragakan dengan demikian mampu meningkatkan keterampilan menulis karangan siswa.

Berdasarkan uraian di atas, maka dapat ditarik kesimpulan bahwa untuk kelas V Sekolah Dasar termasuk berada pada tahap operasional konkret dan termasuk pada kelompok kelas rendah. Anak kelas V Sekolah Dasar berpikir secara realistis, yaitu berdasarkan apa yang ada di sekitarnya. Hal yang perlu diperhatikan oleh guru bahasa Indonesia bahwa anak pada tahap operasional konkret masih sangat membutuhkan benda-benda konkret untuk membantu pengembangan kemampuan intelektualnya. Oleh karena itu, guru seharusnya selalu mengaitkan konsep-konsep yang dipelajari peserta didik dengan benda-benda konkret yang ada di lingkungan sekitar.

\section{Simpulan dan Saran}

Simpulan penelitian ini menunjukkan bahwa: Berdasarkan hasil uji t menunjukkan bahwa analisis test diperolah thitug sebesar 10,239, sedangkan ttabel dengan db N-1 = 29-1 =28, dan taraf signifikan 0,05 sebesar 2,730. Karena thitung> ttabel yaitu 10,239 > 2,730 maka H0 ditolak dan Ha diterima. Jadi dapat disimpulkan bahwa efektif penerapan model pembelajaran Think Talk Write berbantu media gambar seri efektif dalam pembelajaran bahasa Indonesia materi menulis karangan pada siswa kelas V SD Negeri Bugangan 02 Semarang.

Dengan adanya hasil uji t yang menunjukkan bahwa ada perbedaan yang signifikan antara nilai pretest dan posttest. Nilai rata-rata posttest lebih besar yaitu 82,069 dibandingkan dengan nilai rata-rata pretest yaitu 67,966 Sehingga dapat kita ketahui ada peningkatan nilai posttest

\section{Daftar Rujukan}

Agus Suriamiharja, dkk. 1996. Petunjuk Praktis Menulis. Jakarta: Departemen

Akhadiah, Sabarti. 1988. Pembinaan Kemampuan Menulis Bahasa Indonesia. Jakarta: Erlangga.

Arikunto, Suharsimi dkk. 2006. Penelitian Tindakan Kelas. Jakarta: Bumi Aksara.

Arikunto, Suharsimi. 2008. Manajemen Pendidikan. Yogyakarta: Aditya Media

Ariyanti Dwi Pratiwi, Ach. Fatchan, Purwanto . Penerapan Model Pembelajaran Think Talk Write (TTW) Untuk Menıngkatkan Kemampuan Berkomunıkası Sıswa Secara Tertulıs. Universitas Negeri Malang. 
Dewayani, Dian Ayu. 2016. Model Pembelajaran Think Talk Write (TTW) Terhadap Hasil Belajar Pemecahan Soal Cerita Bilangan Bulat Matematika Siswa Tunarungu. Jurnal Pendidikan Kusus Vol. 8 No. 1 Hal. 1-16. Tersedia Pada: https://jurnalmahasiswa.unesa.ac.id/index.php/jurnalpendidikan-khusus/article/view/16101/14617.

Djamarah, Syaiful Bahri. 2010. Strategi Belajar Mengajar. Jakarta: PT Rineka Cipta.

Djuraid, Husun. 2009. Panduan Menulis Berita. Malang: UMM Press.

Enre, Fahrudin. 1998. Dasar-dasar Keterampilan Menulis. Jakarta: Depdikbud.

Firdaus, Lyus. 2010. Komik Sebagai Media Pembeljaran Bahasa Arab. Jurnal Al 'Arabiyah Vol 3 (No. 1 bulan Juli 2006). Diakses dari digilib.uin- suka.ac.id/view/subjects/jur=5Farbyh.html pada tanggal 2 Maret 2015 pukul 17.00 WIB.

Hamdayama, Jumanta. 2014. Model Dan Metode Pembelajaran Kreatif Dan Berkarakter. Bogor: Ghalia Indonesia.

Hartanto. 2017. Penerapan Model Pembelajaran Think Talk Write (TTW) dengan Bantuan Lembar Kerja Siswa untuk Meningkatkan Aktivitas dan Hasil Belajar IPA Terpadu Siswa Kelas VII A SMP Negeri 2 Rantau Panjang. Jurnal Inovasi Dan Pembelajaran Fisika Vol. 4 No. 1 Hal. 10-17. http://fkip.unsri.ac.id/index.php/menu/104.

Hastuti, Sri. 1982. Tulis Menulis. Yogyakarta: Penerbit Lukman.

Irmayati, Resi, Ali Imron dan Suparman Arif. 2015. Pengaruh Model Think Talk Write (TTW) terhadap Hasil Belajar IPS Siswa. Pesagi (Jurnal Pendidikan dan Penelitian Sejarah). Vol. 3 No. 5 Hal. 1-12. Tersedia Pada: http://jurnal.fkip.unila.ac.id/index.php/PES/article/view/10135/pdf_143.

Iru, La dan Arihi L.S. 2012. Analisis Penerapan Pendekatan, Metode, Strategi, dan Model-model Pembelajaran. Jogjakarta : Multi Presindo.

Ratna ,Setya (2017). Keefektifan Model Pembelajaran Think Talk Write (Ttw) Terhadap Kemampuan Menulis Cerita Ditinjau Dari Minat Menulis Pada Siswa Kelas Iv Sekolah Dasar. PGSD FKIP Universitas Sebelas Maret ISSN : 2337 - 8786.

Setiyaningrum, Erin, dan Istiqomah. 2015. Efektivitas Penerapan Model Pembelajaran Think - Talk - Write terhadap Prestasi Belajar Matematika Siswa Kelas VII SMP Negeri 3 Magelang. UNION: Jurnal Pendidikan Matematika Vol 3 No 1 Hal. 9-16. Tersedia Pada: http://jurnal.ustjogja.ac.id/index.php/union/article/view/270.

Riansyah, Fahri, Arnida Sari. 2018. Pengaruh Penerapan Pembelajaran Kooperatif Tipe Think Talk Write (TTW) terhadap Kemampuan Pemecahan Masalah Matematika Ditinjau Dari Kemampuan Awal Matematika. Juring: Journal for Research in Mathematics Learning Vol. 1, No. 2, Hal. 119-126. Tersedia Pada: http://ejournal.uin-suska.ac.id/index.php/juring/article/view/5426.

Riski, Riska, Muh. Rizal, Linawati. 2017. Penerapan Model Pembelajaran Kooperatif Tipe Think Talk Write (TTW) untuk Meningkatkan Hasil Belajar Siswa pada Materi Hubungan Sudut Pusat, Panjang Busur, dan Luas Juring di Kelas VIII C SMP Negeri 9 Palu. Jurnal elektronik Pendidikan Matematika Tadulako, Volume 5 Nomor 2, Hal. 175-190. Tersedia Pada: http://jurnal.untad.ac.id/jurnal/index.php/JEPMT/article/view/9097.

Shoimin, Aris. 2014. 68 Model Pembelajaran Inovatif dalam Kurikulum 2013. Jakarta: AR-RUZZ MEDIA.

Susanto, Ahmad. 2013. Teori Belajar Dan Pembelajaran Di Sekolah Dasar. Jakarta: Prenadamedia Group

Tarigan, Henry Guntur. 1994. Metodologi Pengjaran Bahasa Indonesia. Bandung Pustaka Setia. 